\title{
PELATIHAN MANAJEMEN USAHA PADA SENTRA KERAJINAN DI TERMINAL TELUK NARA KABUPATEN LOMBOK UTARA
}

\author{
Irwan Suriadi ${ }^{1}$, M.Mujahid Dakwah'², Himawan Sutanto ${ }^{3}$ \\ Jurusan Ilmu Ekonomi dan Studi Pembangunan - Universitas Mataram
}

irwansuryadi@unram.ac.id

\begin{abstract}
ABSTRAK
Tujuan program ini adalah untuk membantu mitra adalah untuk Menerapkan manajemen usaha yang modern dan pemasaran produk kerajinan melalui media online. Target khusus program PPM Kemitraan ini adalah mampu memasarkan produk kerajinan dengan luas tidak hanya dilokasi penjualan tetapi juga ke seluruh dunia. Metode yang digunakan dalam mencapai tujuan kegiatan ini adalah dengan melakukan pelatihan dan pendampingan.

Kegiatan dari program PPM Kemitraan ini terdiri dari : (1) pelatihan manajemen usaha yang komprehensip dan modern, (2) pelatihan pemasaran produk kerajinan melalui pemsaran onlineyang menjangkau seluruh pasar dunia yang dilakukan oleh Tim PPM Kemitraan.

Hasil program kegiatan pengabdian kepada masyarakat ini adalah pengusaha pengerajin souvenir di teluk nara dapat menerapkan manajemen usaha yang modern yang berbasis pemanfaatan teknologi informasi seperti penerapan manajemen pemasaran yang memanfaatkan media sosial untuk memasarkan produk souvenirnya sehingga produk tersebut dapat terkenal bukan hanya di indonesia bahkan diseluruh dunia dengan bantuan teknologi informasi, kegiatan pengabdian kepada masyarakat ini berbentuk pelatihan dan penyuluhan berkaitan manajemen usaha modern dengan pemanfaatan teknologi informasi, terutama melalui pemasara online. Kegiatan pengabdian ini berjalan dengan lancar dan antusias bagi pengusaha souvenir di teluk nara yang ditnjukkan dengan banyaknya pertanyaan dan diskusi selama kegiatan pelatihan berlangsung.
\end{abstract}

Kata Kunci: Produk Kerajinan, Manajemen Usaha, Teluk Nara KLU. 


\begin{abstract}
The aim of this program is to help partners to implement modern business management and marketing craft products through online media. The PPM Partnership's special program targets to offer handicraft products widely not only in sales but also throughout the world. The method used in achieving the objectives of this activity is by conducting training and assistance.

The activities of the Partnership PPM program consist of: (1) comprehensive and modern business management training, (2) training on the marketing of handicraft products through online marketing held on the world market conducted by the Partnership PPM Team.

The result of this community service program is that souvenir craftsmen in Teluk Nara can implement modern business management based on information technology such as social media management that utilizes social media to market their souvenir products so that these products can be used only in Indonesia for the entire world with the help of information technology. , this community service activity regarding training and delivery of information about modern management using information technology, especially through online marketing. The community service activities went smoothly and enthusiastically for souvenir entrepreneurs in Nara Bay, who were shown various questions and discussions during the training activities.
\end{abstract}

Keywords: Handicraft Products, Business Management, Teluk Nara KLU.

\title{
PENDAHULUAN
}

Usaha Mikro, kecil dan menengah (UMKM) merupakan ujung tombak perekonomian nasional maupun perekonomian daerah, di mana usaha kecil telah terbukti dapat bertahan dari berbagai goncangan krisis ekonomi. Usaha kecil dan menengah saat ini banyak menyerap tenaga kerja dan banyak membantu pemerintah dalam mengatasi pengangguran. Di daerah Nusa Tenggara Barat (NTB) pada umumnya dan pulau Lombok pada khususnya peranan usaha kecil sangat besar dalam menopang perekonomian daerah ini, saat ini kegiatan industri banyak di lalukan oleh usaha kecil dan menengah (UMKM), sedangkan usaha besar yang beroperasi di daerah ini hanya beberapa saja, oleh karena itu sudah saatnya pihak-pihak yang berkepentingan memperhatikan perkembangan 


\section{Jurnal ABDIMAS INDEPENDEN}

Vol. 2, No. 1, Mei 2021

usaha kecil dan menengah (UMKM) untuk kemajuan perekonomian daerah ini.

Pemerintah Kabupaten Lombok Utara melauncing sentra kerajinan di terminal Teluk Nara, Kecamatan Pemenang untuk mengakomodir hasil kerjainan para pegiat Usaha Kecil Menengah yang ada di daerah ini pada bulan Maret 2018, Lombok Utara merupakan kabupaten dengan kunjungan wisata terbanyak di Nusa Tenggara Barat. Karena itu dengan dibukanya pusat oleh-oleh pada sentra kerajinan pada areal Terminal Teluk Nare diharapkan mampu mendongkrak ekonomi masyarakat di Lombok Utara. Gempa bumi yang terjadi pada bulan Agustus 2018 yang lalu menyebabkan usaha kerajinan banyak yang terkena dampaknya sehingga usaha kerajinan di daerah ini perlu bangkit untuk mendukung kerajinan tersebut maka diperlukan adanya kegiatan pemasaran produk yang komprehensip.

Manajemen usaha dibutuhkan oleh para pengrajin yang berada di teluk nara agar produk kerajinan mereka dapat dikenal luas oleh masyarakat dunia sehingga produk kerajinan tersebut akan laku terjual ke berbagai penjuru dunia, tidak hanya mengandalkan dari penjualan di tempat usaha yang minim pengunjung apalagi setelah gempa bumi yang menyebabkan kunjungan wisatawan turun drastic sehingga diperlukan manajemen usaha yang komprehesip dan modern agar produk kerajinan yang berada di teluk nara akan semakin dikenal luas dan diharapkan penjualan akan meningkat sehingga diperlukan adanya pelatihan manajamen usaha pada kerajinan di terminal di teluk nara KLU.

Permasalahan Mitra (1) Manajemen usaha belum diterapkan oleh pengrajin pada sentra kerajinan di teluk nara (2) Pengrajin pada sentra kerajinan di teluk nara KLU belum masih menerapkan manajemen usaha sederhana (3) Pemasaran produk di sentra kerajinan di teluk nara KLU masih sempit dan belum menerapkan pemsaran online (4) Pengrajin pada sentra kerajinan di teluk nara KLU belum menerapkan manajemen produksi dan usaha yang modern sehingga belum termanage dengan baik 


\section{METODE PELAKSANAAN}

Dalam mengatasi permasalahan yang di hadapi mitra dalam kegiatan PPM Kemitraan ini, maka kegiatan yang dilakukan oleh tim adalah sebagai berikut: 1) Pelatihan manajemen usaha, 2) pelatihan pemasaran produk, 3) pelatihan manajemen keuangan, 4) pendampingan manajemen usaha.

Tahapan-tahapan dalam kegiatan PPM Kemitraan ini melalui tahapan persiapan, pelatihan, pendampingan, evaluasi dan laporan, dimana setiap tahapan di tampilkan sebagai berikut:

\section{Tahapan Persiapan}

Pada tahap persiapan ini kegiatan yang dilakukan oleh tim pengabdian pada masyarakat maka akan dilakukan koordinasi dan pertemuanpertemuan permulaan dengan berbagai pihak seperti pihak LPPM Unram, Kepala desa Teluk Nara dan pengusaha kerajinan teluk nara, terutama pengelola sentra kerajinan di teluk nara KLU agar dapat mengumpulkan para pengrajin nantinya ketika pelaksanaan kegiatan pengabdian ini.

Pada tahapan ini juga tim pengabdian juga melakukan komunikasi dengan mitra, instruktur,pemateri lainnya untuk melakukan koordinasi berkaitan dengan teknik pelaksanaankegiatan pengabdian pada masyarakat, terutama yang berkaitan dengan pemberian materi manajemen usaha kerajinan. Pada tahap ini juga mitra menyiapkan semua perlengkapan, bahan, tempat atau lokasi yang berkaitan dengan teknis pelaksanaan kegiatan pengabdian pada masyarakat ini dalam bentuk pelatihan.

\section{Tahapan Pelatihan manajemen usaha}

Pada tahapan ini mitra akan diperkenalkan oleh tim pengabdian pada masyarakat mulai dari pembagian manajemen, tahapan-tahapan manajemen dan strategi manajamen marketing mix agar usaha dapat berjalan dengan baik, kegiatan ini memberikan peran aktif mitra untuk 


\section{Jurnal ABDIMAS INDEPENDEN}

Vol. 2, No. 1, Mei 2021

dapat berinteraksi berkaitan dengan materi manajemen usaha dengan mendapat arahan dan bimbingan dari tim pengabdian pada masyarakat, karena peran aktif dari mitra merupakan bagian kesuksesan dari kegiatan pengabdian pada masyarakat ini.

\section{Tahapan Pelatihan Pemasaran Produk}

Pada tahapan ini mitra akan diperkenalkan cara pemasaran modern terutama pemasaran melalui online yang komprehensip mulai dari menyiapkan foto produk sampai mengupload ke merketplace online yang akan dituju oleh pengusah pengrajin kerajinan di sentra kerajinan teluk nara KLU, pada tahapan ini peran aktif mitra juga sangat penting karena akan berdampak secara langsung dalam memahami tahapantahapanPemasaran online.

\section{Tahapan Pelatihan Manajemen keuangan}

Pada tahapan ini mitra akan diberikan pemahaman tentang cara membuat. Laporan keuangan sederhana dan laporan penjualan yang dapat dibuat setiap hari bahkan setiap bulan agar semua transaksi keuangan akan tercatat pada buku akuntansi. Metode penyampaian materi menggunakan penyampain dua arah dan peran serta dari mitra. Pada tahap ini mitra juga berkewajiban untuk mempersiapkan bahanbahan pelatihan.

\section{Tahapan Pendampingan}

Tahapan pendampingan bertujuan untuk memberikan pemahaman secara komprehensip berkaitan dengan teknis atau cara pengoperasian alat atau peralatan yang akan digunakan dalam kegiatan ini sehingga diharapkan akan dapat mengatasi berbagai permasalahan yang dihadapi mitra yang berhubungan manajemen usaha. Mitra juga diharapkan untuk menyampaikan berbagai permasalahan yang dihadapi dengan tim pengabdian pada masyarakat agar permasalahan tersebut dapat segera dicarikan solusinya. 


\section{Tahapan Evaluasi dan Pelaporan}

Kegiatan evaluasi dan pelaporan menjadi bagian akhir dari kegiatan PPM Kemitraan, evaluasi dilakukan untuk memperoleh informasi secara utuh mengenai target, sasaran yang sudah terpenuhi dan untuk memperoleh gambaran yang berhubungan dengan berbagai kekurangan yang perlu diperbaiki pada kegiatan pengabdian pada tahun-tahun selanjutnya.

\section{HASIL DAN PEMBAHASAN}

Hasil dari kegiatan pengabdian kepada masyarakat ini di Teluk Nare Kabupaten Lombok Utara (KLU) adalah pemahaman masyarakat akan pentingnya penerapan manajemen usaha terutama penerapan manajemen pemasaran dengan pemanfaatan teknologi informasi melalui media sosial atau internet. Materi yang diberikan kepada masyarakat pengusaha souvenir Di Teluk Nare Kabupaten Lombok Utara (KLU) diantaranya Manajemen usaha modern, manajemen pemasaran, pemasaran melalui media social atau internet. Selama ini pengusaha souvenir di Di Teluk Nare Kabupaten Lombok Utara (KLU) belum menerapkan manajemen usaha yang modern terutama manajemen pemasaran yang memanfaatkan media social dalam berbisnis sehingga kegiatan pengabdian kepada masyarakat ini akan dapat memberikan manfaat dan dampak bagi pengusaha souvenir Di Teluk Nare Kabupaten Lombok Utara (KLU). Dengan adanya kegiatan pengabdian kepada masyarakat ini pengusaha souvenir Di Teluk Nare Kabupaten Lombok Utara (KLU) dapat memahami cara-cara memasarkan produknya melalui media social dan tentunya diharapkan akan dapat meningkatkan pendapatan masyarakat di sekitar Teluk Nare Kabupaten Lombok Utara (KLU).

Para pengusaha souvenir Di Teluk Nare Kabupaten Lombok Utara (KLU) diarahan untuk mempraktekkan langsung materi yang didapat saat kegiatan pengabdian berlangsung dengan melakukan pemasaran online malalui handphone dengan mudah, selain itu sebelum pengusaha souvenir 


\section{Jurnal ABDIMAS INDEPENDEN}

Vol. 2, No. 1, Mei 2021

Di Teluk Nare Kabupaten Lombok Utara (KLU) memasarkan produknya melalui media social atau online, maka pengusaha souvenir Di Teluk Nare Kabupaten Lombok Utara (KLU) harus memfoto produk kerajinan mereka terlebih dahulu kemudian mengupload semua foto produknya sehingga dapat langsung terlihat di media social atau internet. Hal ini dilakukan agar hasil dari pemasaran online melalui media social dapat dilihat secara cepat dengan membuka media social. Setelah kegiatan pengabdian Di Teluk Nare Kabupaten Lombok Utara (KLU) terlaksana, pengusaha souvenir harus melihat dengan baik peluang-peluang lain yang mungkin muncul dari media social yang berkaitan dengan desain souvenir yang terbaru yang mengikuti trend masyarakat dunia agar produk kerajinan souvenir Di Teluk Nare Kabupaten Lombok Utara (KLU) selalu disukai oleh konsumen baik konsumen domestic maupun konsumen internasional.

Berdasarkan tingkat partisipasi peserta pelatihan kegiatan pengabdian pada masyarakat ini berlangsung dengan baik dan lancar. Ukuran keberhasilan dari kegiatan pengabdian pada masyarakat ini adalah jumlah peserta yang memenuhi target yang direncanakan, maka boleh dikatakan kegiatan ini berhasil dan terlaksana dengan baik.

Hambatan dan keberhasilan selama kegiatan pengabdian pada masyarakat ini adalah sebagai berikut:

1. Hambatan

Hambatan yang dihadapi oleh peserta pelatihan adalah banyaknya peserta yang masih sibuk bekerja sehingga tidak dapat mengikuti kegiatan pengabdian pada masyarakat sehingga tidak dapat mengikuti kegiatan pelatihan

2. Pendorong keberhasilan

Peserta pelatihan sangat antusias dalam mengikuti kegiatan pengabdian pada masyarakat yang berkaitan dengan peningkatan jumlah produksi dan pengemasan produkkarena peserta dapat 
langsung berinteraksi dengan pemateri. Selain itu juga peserta sangat aktif bertanya pada sesi tanya jawab selama kegiatan pengabdian pada masyarakat berlangsung karena kegiatan pelatihan ini sangat penting dan berimplikasi langsung pada peningkatan penjualan produk secara bagi pengusaha souvenir di teluk nara KLU.

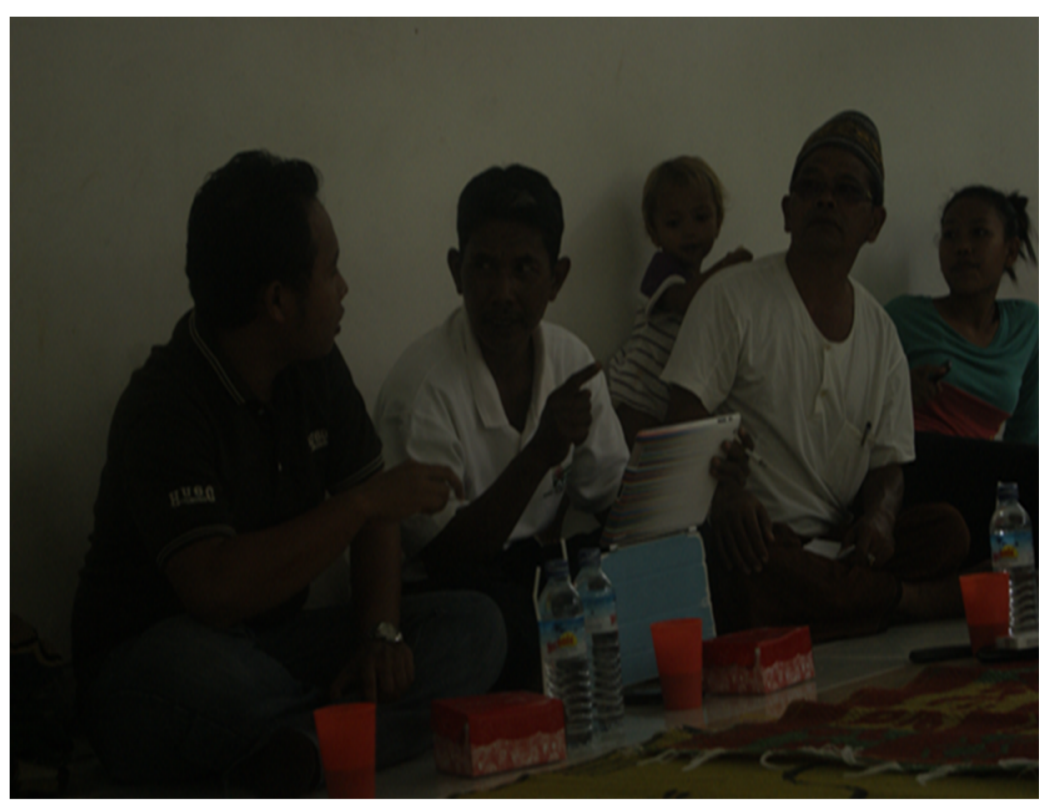

Gambar1: Kegiatan Pengabdian

\section{SIMPULAN DAN SARAN}

\section{Kesimpulan}

1. Pengabdian pada masyarakat telah dilaksanakan dan berjalan dengan baik dan lancar tanpa adanya halangan yang berartiserta antusiasme para peserta yang cukup baik yang dapat dilihat dari jumlah peserta yang hadir sebanyak 16 orang peserta dan cukup interaktif dalam diskusi tentang Menajemen usaha dan pemassaran online produk kerajinan melalui media sosial yang diharapkan akan dapat meningkatkan penjualan produk souvenir bagi pengusaha souvenir di teluk nara KLU.

2. Dengan adanya kegiatan pengabdian kepada masyarakat dalam bentuk pelatihan ini, masyarakat pengusaha souvenir di teluk nara KLU dapat meningkatkan Penjualan produk souvenir mereka sehingga produk 


\section{Jurnal ABDIMAS INDEPENDEN}

Vol. 2, No. 1, Mei 2021

tersebut akan cepat laku dipasaran melalui pemasaran secara online sehingga akan meningkatkan pendapatan masyarakat sekitar yang hanya selama ini mengandalkan pendapatan dari satu jenis usaha saja

3. Pengusaha souvenir sangat memahami arti pentingnya Pemasaran online, apalagi saat ini pemasaran online sedang berkembang dengan pesat sebagai salah satu kekuatan dari suatu produk, penjualan produk banyak atau sedikit sangat tergantung kegiatan pemasaran yang digunakan, oleh karena itu dengan adanya pelatihan manajemen ussaha dan pemasaran online ini masyarakat dapat memahami pentingnya penggunaan pemasaran online di era saat ini karena akan sulit bagi suatu produk untuk berkembang jika tidak dipasarkan secara online

4. Pengabdian kepada masyarakat di teluk nare KLU ini juga dilakukan untuk memberikan pelatihan dan pemahaman tentang tata cara Memasarkan produk souvenir secara online melalui media social karena suatu produk dikenal baik oleh konsumen tergantung dari jenis strategi pemasaran apa yang digunakan oleh pengusaha.

\section{Saran}

1. Kegiatan pengabdian pada masyarakat ini merupakan langkah awal bagi masyarakat di teluk nare KLU agar dapat meningkatkan pendapatan mereka dengan berwirausaha dalam Meningkatkan penjualan produk mereka dikemudian hari dengan adanya kegiatan pengabdian pada masyarakat ini. Untuk memaksimalkan hasil kegiatan pelatihan ini perlu adanya kegiatan pengabdian selanjutnya yang berkaitan dengan manajemen usaha pada suatu produk terutama pemasaran online produk yang berkaitan dengan produk souvenir

2. Agar pengabdian pada masyarakat ini dirasakan langsung manfaatnya oleh para peserta, maka perlu adanya evaluasi dan pendampingan terhadap para peserta / masyarakat di Teluk Nare KLU yang berkaitan 
dengan Pemasaran produk souvenir dan manajemen usahaagar benarbenar mempraktikkan materi yang telah diterima pada pelatihan/penyuluhan yang diterima oleh masyarakat di Teluk Nare KLUterutama dalam memasarkan produk secara online dengan media sosial

\section{UCAPAN TERIMA KASIH}

Pelaksanaan kegiatan Pengabdian Kepada Masyarakat ini telah melibatkan berbagai pihak, oleh karena itu pada kesempatan ini kami mengucapkan terima kasih dan penghargaan kepada :

1 LPPM UNRAM selaku koordinator pelaksanaan pengabdian kepada masyarakat.

2 Fakultas Ekonomi dan Bisnis Universitas Mataram dan BP2EB Fakultas Ekonomi dan Bisnis Universitas Mataram.

3 Masyarakat Teluk Nare Kabupaten Lombok Utara.

\section{DAFTAR PUSTAKA}

Subanar.1998. Manajemen Usaha Kecil. Edisi Pertama. BPFE Universitas Gadjah Mada. Jogjakarta.

Umar, Husain. 2003. Business an Introduction. Gramedia Pustaka Utama, Jakarta.

Susanti, Ariani. Modul pelatihan desain merek dan kemasan. Direktorat jenderal industry kecil dan menengah Departemen Perindustrian. Mataram tahun 2008. 